\title{
Sustainable Post-Mining Reclamation for Community Welfare in Ijobalit Village, East Lombok District, West Nusa Tenggara Province
}

\author{
I Gusti Ayu Gangga Santi Dewi ${ }^{1}$, Bambang Eko Turisno ${ }^{2}$ \\ \{ganggasanti@gmail.com ${ }^{1}$, beturisno@yahoo.com² \\ Universitas Diponegoro, Indonesia ${ }^{1,2}$
}

\begin{abstract}
With a high population growth rate with pumice mining, East Lombok Regency has resulted in many holes in the ground. The research objective was to determine the sustainable benefits of post-mining reclamation in Ijobalit Village, East Lombok Regency, and the benefits of mining product areas for the community's welfare in East Lombok Regency, West Nusa Tenggara Province. This research can be broadly grouped into the realm of the Social Legal approach. In this case, there are two aspects of research: the legal research aspect, namely the object of research still exists in the form of law in the meaning of "norms" and social research, namely the use of methods and social science theories about the law. Based on the research results, the utilization of post-pumice mining reclamation in East Lombok Regency, West Nusa Tenggara Province, can improve the surrounding community's welfare. Post-mining reclamation land results are used to expand existing community lands, such as developing plantations and tourism objects.
\end{abstract}

Keywords: Post-Mining Reclamation, Plantation, Tourism, Welfare

\section{Introduction}

Reclamation, in theory means an attempt to form new plains to meet the demand for land by hoarding areas [1]. Reclamation is an effort to increase natural land resources from economic, social, and environmental aspects by draining land or landfilling by adding a specific land volume into the sea and coastal areas. Reclamation is an activity of landfilling by incorporating some materials into coastal areas that are continuously flooded to obtain dry land on which buildings can be erected as a joint effort for the public interest [2][3].

Article 26 of the Presidential Decree of the Republic of Indonesia No. 122 of 2012 concerning Reclamation in Coastal Areas and Small Islands states that the implementation of reclamation is obliged to maintain and pay attention to: a) Sustainability of life and community livelihoods; b) The balance between the interests of utilization and the interests of the conservation of the coastal environment's functions and small islands; and c) Technical requirements for material picking, dredging, and stockpiling [4][5].

The positive impact of pumice mining is an increase in the area's quality and economic value, reduce unproductive land, and improve the condition of aquatic habitats for community use. It is feared that the mining process that has not been going well will cause negative impacts, such as more material being washed away, resulting in silting of the waters. If it continues, it will threaten the ecosystem [6][7]. 
Various activities can prevent pumice mining with negative impacts according to the requirements permitting in environmental impact, location, and reclamation implementation that have been regulated in the applicable regulations. Suppose the conditions in the permit application are not implemented. In that case, the implementation of pumice mining can be rejected or even canceled by the government even though the reclamation results have been carried out.

Pumice mining in East Lombok Regency has a positive influence on the Regional Government of East Lombok Regency and the surrounding community with the results of the water sources. Previously, the village area of Ijobalit was a dry, barren area which was very difficult to get water. The results of pumice mining in East Lombok Regency in getting springs and tourism are seen as a prospect that brings some benefits for the general welfare.

The problems in this research are: 1) what is the potential for pumice mining in East Lombok Regency as a sustainable land area; 2) what are the benefits of pumice mining in East Lombok Regency.

\section{Methods}

\subsection{Research Approach}

This research can be broadly grouped into the Social Legal approach's realm [8]. This research is carried out by reconstructing social reality by prioritizing the interaction between research and what is studied through sources and informants and paying attention to the context that shapes the input, process, research results, and interpretations.

\subsection{Research Sites}

The pumice mining area that has been managed as a tourist area and a part of the area as a plantation business is a potential utilized by the surrounding community. The research location will be carried out in the reclaimed pumice mining area in East Lombok Regency by looking at the conditions of land management as a residence and place of business and pre-existing tourism development.

\subsection{Data Source}

In this study, the sources of data were extracted from informants. Especially, residents who carry out pumice mining have benefited from reclaimed land, village officials around the research location, the National Land Agency of East Lombok Regency, the Environment and Forestry Service of NTB Province and the NTB Province ESDM Service. Meanwhile, the legal material in this research includes national law.

\subsection{Data Collection Technique}

Techniques for finding primary data, carried out through free/open or unstructured interviews directly with respondents met, are considered necessary for providing data in this study. This research is field research using the Verstehen or hermeneutic approach. Also, observations are made to obtain data about the research location in its physical aspects, such as 
land-use patterns resulting from reclamation, land control, and community attitudes towards pumice mining.

To complement this research is by a library research on the theory of benefits which is associated with progressive law for society's welfare and positive law in the form of regulations, laws and policies related to reclamation.

\subsection{Data Processing and Analysis Techniques}

The research was conducted through source and method triangulation techniques. Source triangulation is done by compare multiple data from various sources to systematize similarities and differences in views based on source situations when submitting data, qualifications, and their suitability with documents that become research data.

Triangulation method was carried out by conducting a strategy of checking through indepth interviews and data collection techniques of participatory observation, especially the data collection of parties related to pumice mining in East Lombok Regency.

The interactive analysis was carried out using field notes consisting of descriptions and data reflections [9]. Classifying data is by through sorting, filtering, indexing and grouping. The results of the study are considered valid and reliable, then reconstruct and analyze the problem inductively qualitatively, starting from observations of specific problems, then drawing general conclusions [10].

This steps of data analysis technique in this research follow an interactive data analysis model that includes three activity, namely: data processing and reduction, data presentation, and making conclusions or verification. The conclusions in question are not conclusions equivalent to generalizations [11].

\section{Discussion and Results}

\subsection{Pumice Mining in East Lombok Regency Potential}

East Lombok Regency has some tourist locations divided into several categories: Nature Tourism, Religious Tourism, Historical Tourism, and Culinary and Family Tourism. The number of tourism objects makes East Lombok Regency visited by tourists from Bali and Sumbawa almost every weekend, even foreign tourists. It is also since East Lombok Regency has the potential for beautiful physical nature and hills due to its geographical location.

East Lombok Regency is a suburban city with several potentials to be developed as a tourist area considering its very strategic position with a variety of supporting activities. One of the efforts to develop tourism is by utilizing land from pumice mining in East Lombok Regency.

The result of pumice mining used as a tourist attraction involves the surrounding community. Pumice mining areas for plantation and tourism businesses can revive the surrounding community's economic activities, such as making handicrafts for sale as souvenirs, as well as restaurant businesses and others that are very beneficial to the surrounding community.

The study results found that tourism development in the post-mining pumice area received a positive response from the East Lombok Regency government. The government has provided various assistance, such as the arrangement in the post-mining area-both funds and skills from the local government and supporting facilities. 
Several factors, including support the development of a pumice mining product area for plantations and tourism objects in East Lombok Regency

a. Economic Factors

The development of pumice mining product areas for plantations and tourism objects requires costs for the construction of irrigation and various activity service facilities such as swimming, sports tours, restaurants, and visual beauty that is unique to attractive water areas. It is necessary to provide funds for management related to the ability of the community and local government policies to manage post-mining areas as tourism objects. Therefore, both local and provincial governments need a role and financial assistance by involving local Village-Owned Enterprises (Bumdes).

b. Social Factors

The pumice mining product area's development is informed clearly, transparently, and completely covering, among other things, management, financing, and Environmental Licenses. The community provides input, suggestions and aspirations for the government in determining its policies.

c. Cultural Factors

The post-pumice mining area is a tourist attraction with specific characteristics by local culture. Local custom history gives a particular culture identity. It gives a particular identity to the area and creates a certain attraction with specific characteristics from one location to another based on local ecological, climatic, historical, or socio-cultural characteristics [12].

d. Environmental factor

Post-mining development in Ijobalit Village prevent negative impacts on the environment and utilizing less productive land to protect the environment by preventing negative impacts on the environment and utilizing less productive land. A development project with the selection of materials to be used, particularly waste management, prevents damage to soil ecosystems and natural forest resources by considering long-term sustainability factors [13]. Integrated and sustainable supervision of post-mining land development will work well with the natural resources and human resources around it. The development of pumice mining product areas for plantations is oriented towards environmental cleanliness by preventing pollution. Meanwhile, the development of the potential of the pumice mining product area for tourism is based on efforts to improve environmental quality by utilizing the authenticity of the environment that grows naturally, such as the forest around the post-mining area.

\subsection{Benefits of Land after Pumice Mining in East Lombok Regency}

The management and utilization of post-mining land are permitted by law, as long as it considers the limited carrying capacity, sustainable development, linkages of ecosystems, biodiversity, and the preservation of environmental functions. It is as stipulated in Article 15 of Law No. 16 of 2004 concerning Land Use, which reads: "The use and utilization of land on small islands and land parcels located on borders, lake boundaries, reservoir boundaries, and/or boundaries. Rivers must pay attention to the public interest and limited carrying capacity, sustainable development, the linkage of ecosystems, biodiversity and the preservation of environmental functions" [14].

The utilization of the pumice mining area in East Lombok Regency is aimed at residential areas with plantation business and beneficial for the survival and preservation of natural resource ecosystems. The community's authority to utilize land in forestry areas is also explained in the Explanation of Agrarian Law Number II point 2, which states that "The State can give land controlled by the State to a person or legal entity with a right according to its 
designation and necessity. For example, property rights, right to cultivate, the right to build or use rights or give it in the management of an agency (Department, Bureau or Swantara Region)".

Based on the explanation of Agrarian Law, the state can give land controlled by the state to citizens in need. Applications for land rights after pumice mining are aimed to the government either by by legal entities or individuals based on the laws and regulations [15].

The land from the post-mining reclamation in Ijobali Village is used for plantations and for tourism which is managed by the surrounding community in collaboration with the government and to expand their land for a any specific purpose, namely inter-plantation business. The community is very enthusiastic that the land from the pumice mining product is used for tourism development in their area to improve their standard of living.

\section{Conclusion}

The potential of pumice mining land for plantations and tourism objects by involving the surrounding community in managing the post-mining area can improve the community's welfare. Pumice mining areas for plantation and tourism businesses can revive the surrounding community's economic activities, such as making handicrafts for sale as souvenirs and restaurant businesses and others, including forest conservation whose leaves and trees can be made home industry. Forest conservation in areas resulting from post-mining reclamation with land development facilities is sustainable cultivation of natural resources and human resources.

Based on Government Regulation No. 16 of 2004 concerning Land Use, the use of land from pumice mining in coastal areas is permitted by law, as long as it takes into account the limited carrying capacity, sustainable development, linkages of ecosystems, biodiversity, and the preservation of environmental functions. Utilization of the pumice mining area in East Lombok Regency and plantations as well as useful tourism objects for the continuity and preservation of natural resource ecosystems.

\subsection{Suggestion}

Theoretically, the development of potential in post-mining areas can be followed up with further any similar research for other reclamation of post-mining areas. This research was conducted in collaboration with local government agencies related to post-mining reclamation policymakers. The research was carried out with an in-depth post-mining study involving interested and competent parties as well as a comprehensive interdisciplinary science.

In practical terms, the use of mining product areas supports an increase in tourist visits both at home and abroad. The development of rock mining reclamation results is expected to have cooperation and partnerships between the government and investors.

\section{References}

[1] J. M. Patlis, T. H. Purwaka, A. Wiyana, and G. H. Perdanahardja, "Menuju Harmonisasi Sistem Hukum Sebagai Pilar Pengelolaan Wilayah Pesisir Indonesia," Seri Inisiat. Harmon. Sist. Huk. Pengelolaan Wil. Pesisir Indones. Kementrian Perenc. Pembang. Nasional, Dep. Kelaut. dan Perikanan, Dep. Huk. dab HAM bekerja sama dengan Coast. Resour. Manag. Proj. II (USAID). Jakarta, 2005.

[2] R. Refliss, "Reklamasi dan Restorasi Ekologi Kawasan Tanjung Api-Api Provinsi Sumatera 
Selatan,” J. AGRISEP Kaji. Masal. Sos. Ekon. Pertan. dan Agribisnis, vol. 16, no. 1, pp. 57-70, 2017.

[3] G. S. Dewi, "Penolakan masyarakat terhadap reklamasi teluk benoa provinsi bali," Diponegoro Priv. Law Rev., vol. 4, no. 1, 2019.

[4] R. Yulianti, M. Ikhwan, and N. Zaman, "Urgensi Pengaturan Reklamasi Pantai di Wilayah Pesisir Selatan Madura," Yust. J. Huk., vol. 4, no. 1, pp. 103-121, 2015.

[5] Z. Hidayah and O. S. Suharyo, "Analisa perubahan penggunaan lahan wilayah pesisir Selat Madura," Rekayasa, vol. 11, no. 1, pp. 19-30, 2018.

[6] E. Retnowati, "Nelayan indonesia dalam pusaran kemiskinan struktural (perspektif sosial, ekonomi dan hukum)," Perspektif, vol. 16, no. 3, pp. 149-159, 2011.

[7] H. Djainal, "Reklamasi pantai dan pengaruhnya terhadap lingkungan fisik di wilayah kepesisiran Kota Ternate," J. Lingkung. Sultan Agung, vol. 1, no. 1, pp. 16-28, 2021.

[8] S. Rahardjo, Lapisan-lapisan dalam Studi Hukum. Malang: Banyumedia Publishing, 2009.

[9] H. B. Sutopo, Metode Penelitian Kualitatif, Bagian II. Surakarta: Universitas Sebelas Maret Surakarta Press, 1990.

[10] S. Sudarto, Metode Penelitian Filsafat. Jakarta: Raja Grafindo, 2002.

[11] D. Karnawati, "Mekanisme gerakan massa batuan akibat gempabumi; tinjauan dan analisis geologi teknik," Din. Tek. Sipil, vol. 7, no. 2, pp. 179 - 190, 2007.

[12] S. Asiyah, "Analisis Perubahan Permukiman Dan Karakteristik Permukiman Kumuh Akibat Abrasi Dan Inundasi Di Pesisir Kecamatan Sayung Kabupaten Demak Tahun 2003-2013 (Implementasi Pengayaan Materi Pembelajaran Geografi Di Sma Pada Kelas Xi Semester Ii Kurikulum Tingk," Undergraduate thesis UNS (Sebelas Maret University), 2014.

[13] E. Suganda, P. Atmodiwirjo, and Y. A. Yatmo, "Pengelolaan lingkungan dan kondisi masyarakat pada wilayah hilir sungai," Hubs-Asia, vol. 10, no. 1, 2011.

[14] M. C. Huda, "Pengaturan Perizinan Reklamasi Pantai Terhadap Perlindungan Lingkungan Hidup," Perspektif, vol. 18, no. 2, pp. 126-135, 2013.

[15] B. Harsono, Hukum Agraria Indonesia. Jakarta: Djambatan, 2003. 